\title{
Actualia
}

Mr. T. de Vette*

\section{Jeugdhulp en jeugdbescherming}

\section{Nieuws}

\section{Inspecties: RvdK heeft onvoldoende zicht op veiligheid kinderen op wachtlijst}

De Raad voor de Kinderbescherming (RvdK) heeft onvoldoende zicht op de veiligheid van kinderen die wachten op een onderzoek. Maatregelen die zijn getroffen om dit te verbeteren, beperken de risico's onvoldoende. Dit constateren de Inspectie Justitie en Veiligheid en de Inspectie Gezondheidszorg en Jeugd na toetsing van deze maatregelen in de praktijk. De maatregelen kunnen niet bijdragen aan beter zicht op de veiligheid van het kind wanneer de RvdK geen goed beeld heeft van de wachtlijst. Lange wachtlijsten zijn van negatieve invloed op het overzicht van wachtende kinderen, het prioriteren van onderzoeken en de haalbaarheid van de maatregelen. Eind januari 2019 wachtten bijna 2800 kinderen gemiddeld dertig dagen op onderzoek, terwijl tien dagen de norm is. De RvdK dient beter zicht te krijgen op hun veiligheid. Daarbij verwachten de inspecties dat de RvdK nu afspraken makkt met de partners in de jeugdbeschermingsketen over ieder kind dat wacht op onderzoek. De inspecties volgen de RvdK intensief, uit zorg voor de veiligheid van de kinderen. De RvdK dient elke vier maanden een voortgangsrapportage op te leveren.

(Inspecties $\mathcal{F}$ en V en Gezondheidszorg en feugd)

\section{Aantal gezinshuizen stijgt met ruim twintig procent}

Nederland telde in 2018937 gezinshuizen; ruim twintig procent meer dan in 2016. Daar werden vorig jaar 3113 kinderen en jongeren geplaatst, blijkt uit de factsheet Gezinshuizen van Gezinspiratieplein. De meeste gezinshuizen zijn verbonden aan een jeugdhulpaanbie- der, bijvoorbeeld in loondienst of als onderaannemer. De jeugdhulpaanbieder is dan verantwoordelijk voor de zorg. Voor het eerst heeft Gezinspiratieplein het aantal gezinshuizen geïnventariseerd waar gemeenten rechtstreeks plaatsen inkopen. Gezinspiratieplein vond 43 gezinshuizen die deels of geheel met rechtstreekse inkoop werken.

(NFI, Gezinspiratieplein)

\section{Promotie: 'Repressie belemmert effectieve behandeling jeugdzorg'}

Repressie in de residentiële jeugdzorg staat een effectieve behandeling van jongeren in de residentiële jeugdzorg in de weg. Dat blijkt uit het promotieonderzoek van Sophie de Valk over repressie in de jeugdzorg, waarop zij op 6 februari 2019 bij de UvA promoveerde. Kleinschalige en gezinsgerichte behandelingen kunnen helpen om repressie tegen te gaan. In haar onderzoek komt De Valk tot een definitie en oorzaken van repressie in de residentiële jeugdzorg. Deze inzichten helpen om repressie in de praktijk te herkennen en zo nodig te verminderen. Repressie is het doelbewust handelen van medewerkers waarbij jongeren schade oplopen. Het kent ook een subtielere vorm, wanneer de vrijheid of autonomie van jongeren onwettig of willekeurig wordt ingeperkt. Repressie veroorzaakt stress bij zowel jongeren als medewerkers, leidt vaak tot meer probleemgedrag en belemmert de effectiviteit van de behandeling. Het blijkt dat de veranderingen en onzekerheden die de transformatie in de jeugdzorg met zich mee hebben gebracht, de kans op repressie onbedoeld vergroten. Zo kampen veel instellingen momenteel met personeelstekorten, waardoor 
de behandelrelatie tussen jongeren en medewerkers onder druk komt te staan. Tegelijkertijd biedt de transformatie ook kansen om nieuwe vormen van jeugdzorg te stimuleren die repressie kunnen uitbannen.

(UvA)

\section{Ombudsman: Jeugdbescherming Gelderland neemt voldoende regie in complexe echtscheidingszaak}

Verzoekster (transgender-ouder) was verwikkeld in een complexe echtscheidingsproblematiek. $\mathrm{Zij}$ had al een jaar geen omgang meer met haar kinderen, toen de rechter een ondertoezichtstelling (OTS) uitsprak. De rechter vond het voor de kinderen belangrijk dat de jeugdbeschermer zou werken aan het contactherstel met verzoekster. De OTS werd een jaar later verlengd, omdat ouders vanwege hun strijd nog steeds niet adequaat over de kinderen communiceerden. Jeugdbescherming kreeg als taak deze patstelling tussen ouders te doorbreken, door de regie te voeren en hulp in te zetten. Verzoekster klaagde erover dat Jeugdbescherming zich niet heeft gehouden aan de opdracht van de rechtbank. Zo heeft Jeugdbescherming niet genoeg gedaan om de communicatie tussen ouders te verbeteren. Ook de bezoekregeling met verzoeksters zoon kwam maar niet van de grond. Toen de uitvoering van de OTS stagneerde, greep Jeugdbescherming volgens verzoekster onvoldoende in. Daarnaast voelde verzoekster zich door Jeugdbescherming bij hen op kantoor (indirect) gediscrimineerd. Jeugdbescherming deed namelijk niets als haar ex-partner tijdens gezamenlijke gesprekken discriminerende en kwetsende opmerkingen makte. De ombudsman overwoog dat Jeugdbescherming Gelderland (JbGld) voldoende regie genomen heeft bij de uitvoering van de OTS. Ook bij het bepalen van de aanpak ging JbGld steeds goed voorbereid en zorgvuldigheid te werk. Om goed haar tak uit te kunnen voeren, moet JbGld een onpartijdige houding innemen ten opzichte van beide ouders. De ombudsman overwoog dat het daarom niet aan de jeugdbeschermer is om een waardeoordeel te geven over vermeende discriminatie. Wel mag verzoekster verwachten dat de jeugdbeschermer tijdens een gesprek de-escalerend optreedt als ontoelaatbare uitingen gedaan worden. Uit gespreksaantekeningen van Jeugdbescherming blijkt dat dit ten minste één keer ook is gebeurd. Hiermee laat JbGld zien dat zij weet hoe zij behoorlijk met haar gesprekspartners moet omgaan. De ombudsman vond de klacht over de onderzochte gedragingen van JbGld niet gegrond.

(Nationale Ombudsman)

\section{Jeugdzorg}

\section{Literatuur}

\section{Jeugdrecht en jeugdbescherming}

Gemeenten kampen al geruime tijd met tekorten in de jeugdhulp; dit is geen nieuw verschijnsel en wordt in de media breed uitgemeten. In het afgelopen jaar hebben gemeenten 605 miljoen euro meer uitgegeven aan jeugdhulp dan wat daarvoor was begroot. Vanwege deze grote tekorten heeft de minister van VWS een onderzoek ingesteld naar de omvang en de oorzaken van de voornoemde financiële tekorten in de jeugdhulp.

(Redactie, DD 2019/9)

\section{Kinderbeschermingsmaatregelen}

\section{Nieuws}

\section{Promotie: Legitimiteit en rechtswaarborgen bij gesloten plaatsingen van kinderen: de externe rechtspositie van kinderen in gesloten jeugdhulp bezien vanuit kinder- en mensenrechten}

Op 7 maart 2019 promoveerde Maria de Jong op een onderzoek naar de externe rechtspositie van kinderen in gesloten jeugdhulp. Met dit onderzoek beoogt De Jong om een kinder- en mensenrechtentoetsingskader op te stellen, waaraan de Nederlandse wet en de toepassing getoetst wordt. Het onderzoek biedt ook inzicht in tweehonderd jaar historie. Verder zijn 586 rechterlijke uitspraken over een periode van tien jaar (2008-2017) geanalyseerd. Hieruit blijkt dat een plaatsing vaak gebaseerd is op het inzetten van acute hulp in een situatie waarin niets anders mogelijk lijkt te zijn. Doorgaans wordt daarbij onvoldoende gekeken naar het doel van deze plaatsing en de vrijheidsbeperkingen die dit met zich meebrengt. In het onderzoek komen ten slotte 23 kinderen aan het woord die te maken kregen met een gesloten uithuisplaatsing. Uit het onderzoek blijkt dat de legitimiteit van het op grote schaal toepassen van deze maatregel onder druk staat, met 